\title{
Germinoma in Two Brothers: Case Report
}

\author{
Naoki NITTA, ${ }^{1}$ Tadateru FUKAMI, ${ }^{1}$ and Kazuhiko NOZAKI ${ }^{1}$ \\ ${ }^{1}$ Department of Neurosurgery, Shiga University of Medical Science, Otsu, Shiga
}

\begin{abstract}
We present a third reported case of intracranial germinomas occurring in two brothers. They underwent chemotherapy and radiotherapy after biopsy and are doing well for 10 years and 20 months, respectively. The pertinent literatures are reviewed, and the possible role of heredity in the pathogenesis of familial occurrence of germinomas is discussed.
\end{abstract}

Key words: germinoma, intracranial, brother, suprasellar, tectum

\section{Introduction}

Sons and siblings of patients with testicular germ cell tumors have four- to sixfold and eight- to tenfold increases in testicular germ cell tumor risk respectively, but central nervous system (CNS) germ cell tumors rarely develop in members of the same family. ${ }^{2,4,6,9,12)}$ We report two extremely rare cases of CNS geminomas occurring in two brothers. The family had no other children and presented no evidence of hereditary syndromes.

\section{Case Report}

Patient 1: This Japanese 11-year-old boy was born of healthy parents without consanguinity following a normal pregnancy. He was admitted to the department of pediatrics of our institute with a 1-year history of impairment of visual acuity and a 2-month history of headache and vomiting. Physical examination revealed isocoria $(2.5 \mathrm{~mm})$ with no pupillary light reflex, decreased visual acuity (bilateral < 20/200) and upward gaze palsy. Fundoscopic examination revealed bilateral papilledema. A magnetic resonance imaging (MRI) with contrast enhancement showed a mass lesion in tectum, which was enhanced heterogeneously and caused hydrocephalus (Fig. 1A, B). The patient was transferred to the department of neurosurgery, and underwent open biopsy via occipital transtentorial approach after ventriculoperitoneal shunt. A soft yellowish brown tumor in quadrigeminal plate was partially removed and diagnosed as pure germinoma with two-cell pattern (Fig. 2A). The patient underwent chemotherapy with cis-diamminedichloroplatinum(II) (CDDP) and VP-16 followed by focal radiation therapy (24 Gy in 15 fractions). The tectal mass disappeared

Received April 9, 2012; Accepted June 18, 2012 completely. At present, 10 years postoperatively, the patient is doing well without neurologic deficits and studying in a university. No recurrent tumor has been detected on MRI (Fig. 1C).

Patient 2: A 21-year-old man, the older brother of patient 1, was admitted to the department of pediatrics of our institute with an 18-year history of epilepsy with "continuous spikes and waves during slow sleep" and mental retardation, a 10-year history of short stature and hypothyroidism, and a 3-month history of inappetence, weight loss, and left ptosis. Physical examination revealed left ptosis, anisocoria (right: $3.5 \mathrm{~mm}$; left: 4.0 $\mathrm{mm}$ ), left sluggish pupillary light reflex and restricted movement of left eye in all directions. Magnetic resonance imaging with contrast enhancement showed an intrasellar and suprasellar mass lesion infiltrating into left cavernous sinus and Meckel's cave, which was enhanced heterogeneously (Fig. 1D, E). The patient was transferred to the department of neurosurgery and underwent biopsy via endoscopic transsphenoidal approach. An elastic grayish tumor was partially removed and diagnosed as pure germinoma, with a biphasic population of lymphocytes and larger polygonal cells that were positive for placental alkaline phosphatase and C-kit (Fig. 2B-D). The patient underwent the same treatment like his brother. At present, 20 months postoperatively, the patient is doing well with no oculomotor nerve palsy. The intrasellar and suprasellar mass disappeared completely on MRI (Fig. 1F).

As far as we can trace, there are no abnormalities of possible hereditary origin in their pedigree.

\section{Discussion}

As far as we know, present cases are the third report of germinomas in siblings without hereditary syndromes 

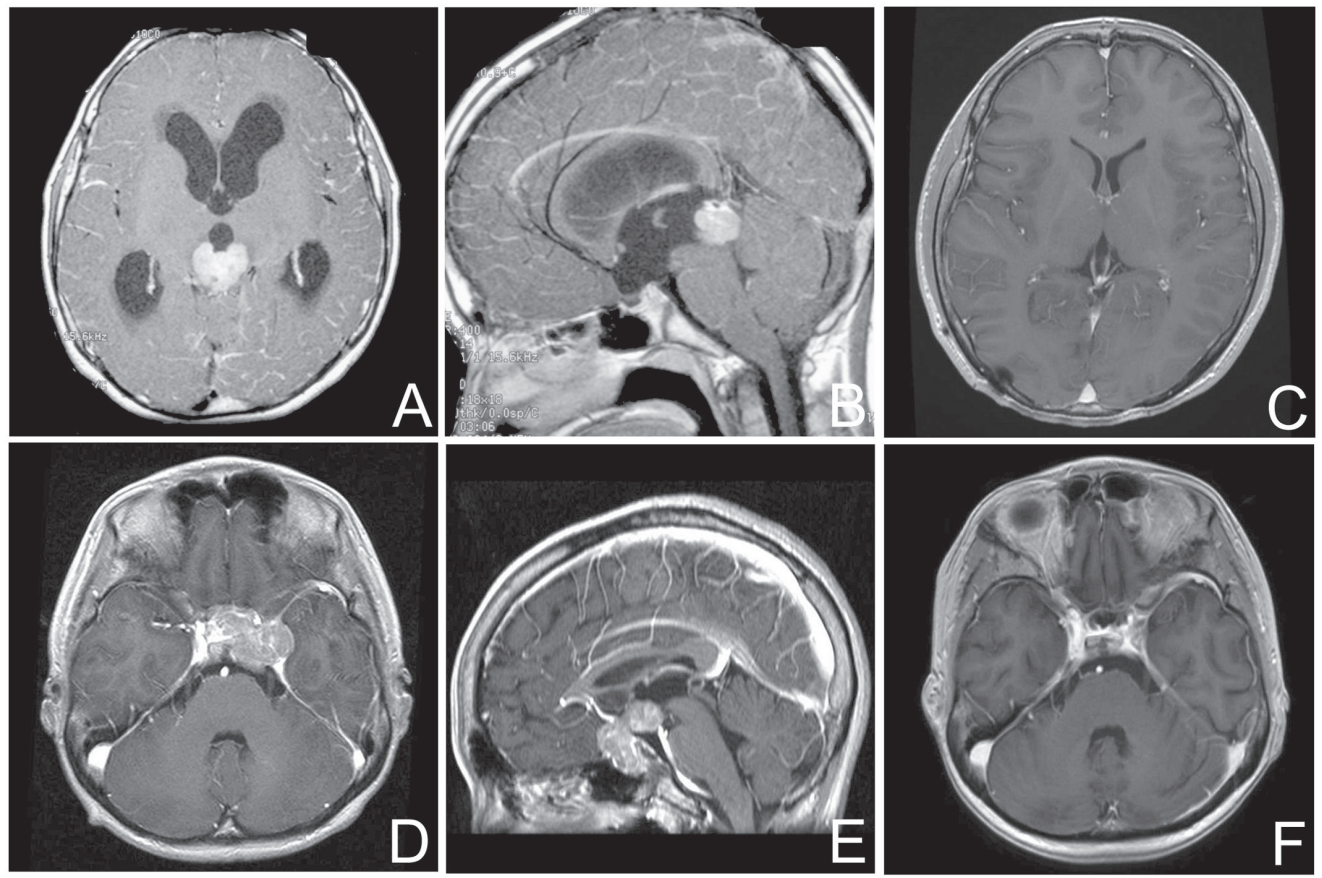

Fig. 1 Preoperative magnetic resonance (MR) scans of patient 1 with contrast enhancement (A, B) showing an enhancing mass lesion in tectum and hydrocephalus. MR scans with contrast enhancement after radiotherapy and chemotherapy (C) showing complete response of the tumor to the treatment. MR scans of patient 2 with contrast enhancement (D, E) showing an enhancing suprasellar and intrasellar mass lesion. MR scans with contrast enhancement after radiotherapy and chemotherapy (F) showing complete response.
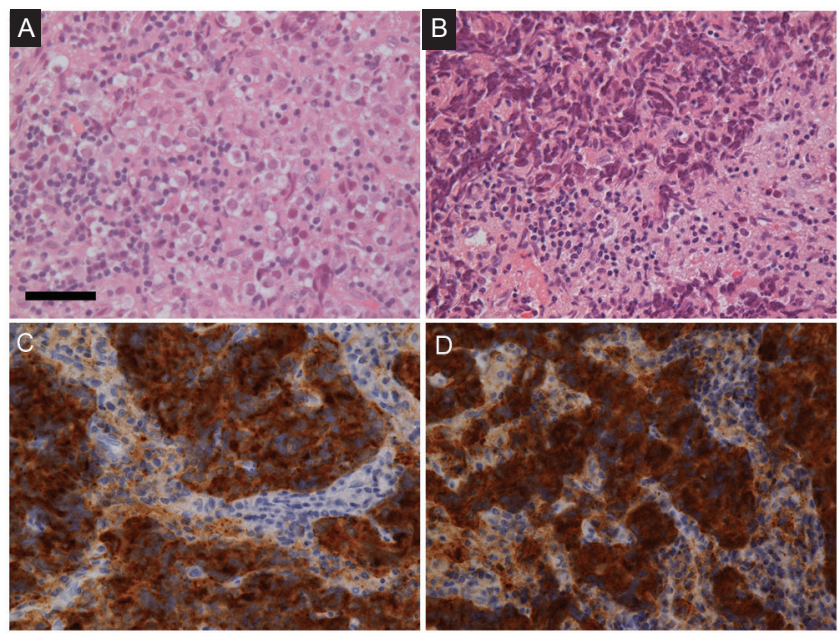

Fig. 2 Light micrographs of the resected tumors of patient 1 (A) and patient 2 (B-D) showing large polygonal cells with large nuclei and lymphocytic infiltrates as "two-cell pattern" geminomas (A, B) and tumor cells positive for placental alkaline phosphatase (PLAP) (C) and C-kit (D) as characteristic features of germinomas. A, B: Hematoxylin and eosin stain, original magnification $\times 400$. C: PLAP immunohistochemical stain, original magnification $\times 400$. D: C-kit immunohistochemical stain, original magnification $\times 400$. Scale bar $=50 \mu \mathrm{m}$ in $\mathrm{A}$.
(Table 1). ${ }^{2,6}$ The clinical course of familial intracranial germ cell tumors described in Table 1 were similar to those of sporadic cases, that is, a favorable prognosis in germinomas and an unfavorable prognosis in the others. These familial germ cell tumors occurred only in siblings, which agree with the fact that over $50 \%$ of reports cite only siblings in familial cases of isolated brain tumor. ${ }^{1)}$ Although familial intracranial germ cell tumor is very rare, the fact that the parents of patients in previous and our reports had no abnormalities of possible hereditary origin suggests that these familial germ cell tumors might be an autosomal recessive disorder, as reported in the analysis of familial testicular germ cell tumors. ${ }^{4)}$ In terms of race, all patients were Japanese. The incidence rate of germ cell tumor in Japan is 0.18 (male: 0.27; female: 0.09) per 100,000 per year, which is twice as high as that in the United States (male: 0.12; female: 0.06 per 100,000 per year)., Japanese race or unknown environmental factors may be associated with an apparently high incidence of the familial occurrence of germ cell tumors in Japan.

Kruppel-like factor 4 Recent studies described that genes responsible for self-renewal (OCT4, NANOG, and KLF4) and six genes (BANK1, CXCL9, CXCL11, DDIT4L, ELOVL6 and HERC5) within 4q13.3-4q28.3 were abundant 
Table 1 Demographic and clinical characteristics of patients in published studies of familial germ cell tumors

\begin{tabular}{|c|c|c|c|c|c|c|c|}
\hline $\begin{array}{l}\text { Authors, } \\
\text { year }\end{array}$ & Sex & Relationship & $\begin{array}{l}\text { No. of unaffected } \\
\text { siblings }\end{array}$ & $\begin{array}{l}\text { Age at symptom } \\
\text { occurence }\end{array}$ & $\begin{array}{l}\text { Survival time } \\
\text { from treatment }\end{array}$ & Tumor location & Histology \\
\hline \multirow[t]{2}{*}{$\begin{array}{l}\text { Wakai et al. } \\
1980\end{array}$} & $\mathrm{M}$ & B & $\begin{array}{l}\text { 1S with no } \\
\text { abnormality }\end{array}$ & 13 & $9 \mathrm{mo}$ & Pineal region & Teratoma \\
\hline & $\mathrm{M}$ & B & & 15 & Alive (for 1 y) & Pineal region & Teratoma \\
\hline \multirow[t]{2}{*}{$\begin{array}{l}\text { Nakasu et al. } \\
1983\end{array}$} & $\mathrm{~F}$ & $\mathrm{~S}$ & $\begin{array}{l}\text { 1S aborted } \\
\text { spontaneously }\end{array}$ & 7 & $12 \mathrm{mo}$ & $\begin{array}{l}\text { Suprasellar } \\
\text { region }\end{array}$ & $\begin{array}{l}\text { Yolk-sac } \\
\text { tumor }\end{array}$ \\
\hline & $\mathrm{F}$ & $\mathrm{S}$ & $\begin{array}{l}\text { 1B with congenital } \\
\text { anomaly of the heart }\end{array}$ & 10 & Alive (for $7 \mathrm{mo}$ ) & $\begin{array}{l}\text { Suprasellar } \\
\text { region }\end{array}$ & $\begin{array}{l}\text { Yolk-sac } \\
\text { tumor }\end{array}$ \\
\hline \multirow[t]{3}{*}{$\begin{array}{l}\text { Kido et al. } \\
1984\end{array}$} & $\mathrm{M}$ & B & $\begin{array}{l}\text { 3B with no } \\
\text { abnormality }\end{array}$ & 18 & Alive & Pineal region & Germinoma \\
\hline & $\mathrm{M}$ & B & $\begin{array}{l}2 S \text { with no } \\
\text { abnormality }\end{array}$ & 16 & Alive & Pineal region & Germinoma \\
\hline & $\mathrm{M}$ & B & & 10 & Less than $1 \mathrm{y}$ & Pineal region & $\begin{array}{l}\text { Embryonal } \\
\text { carcinoma }\end{array}$ \\
\hline \multirow[t]{2}{*}{$\begin{array}{l}\text { Aoyama et al. } \\
1993\end{array}$} & $\mathrm{M}$ & B & None & 7 & Alive (for 4 y) & $\begin{array}{l}\text { Left basal ganglia, } \\
\text { thalamus and } \\
\text { frontal lobe }\end{array}$ & Germinoma \\
\hline & $\mathrm{F}$ & $\mathrm{S}$ & & 9 & Alive (for 3 y) & $\begin{array}{l}\text { Suprasellar and } \\
\text { intrasellar region }\end{array}$ & Germinoma \\
\hline \multirow[t]{2}{*}{ Present case } & $\mathrm{M}$ & B & None & 10 & Alive (for 10 y) & Tectum & Germinoma \\
\hline & $\mathrm{M}$ & B & & 21 & $\begin{array}{l}\text { Alive } \\
\text { (for } 20 \mathrm{mo} \text { ) }\end{array}$ & $\begin{array}{l}\text { Suprasellar and } \\
\text { intrasellar region }\end{array}$ & Germinoma \\
\hline
\end{tabular}

B: brother, F: female, M: male, mo: month, S: sister, y: year. *Patient's nationality is Japanese for all cases.

in intracranial germinomas. ${ }^{13)}$ The mutations of c-kit gene, which encodes a receptor tyrosine kinase (KIT) for stem cell factor (SCF) that is important for proliferation of stem cells and germ cells, in intracranial germinomas have also been described in a previous report. ${ }^{8,11)}$ In a genome-wide association study for testicular germ cell tumors, a strong evidence for susceptibility loci was detected on chromosome 12 , chromosome 5 , and chromosome $6^{5,{ }^{5}(0)}$ The single nucleotide polymorphisms (SNPs) implicated on chromosome 12 are within the c-KIT ligand gene region, those implicated on chromosome 5 are very close to the SPRY 4 gene, which is related in the KITLG-KIT signaling pathway, and those implicated on chromosome 6 are within the BAK1 gene, whose expression is repressed by the KITLG-KIT pathway. Although the affected genes are different between testicular germinomas and intracranial germinomas, it is conceivable that deregulation of KITLGKIT signaling pathway renders not only testicular germ cells but also intracranial germ cells more susceptible to somatic mutations required for neoplastic transformation. ${ }^{4)}$ The cause of familial germ cell tumor is wrapped in mystery, further genetic analysis would provide us a clue to explain its mechanism.

\section{Conclusion}

We present the third reported case of intracranial germinomas occurring in siblings. Japanese race, unknown environmental factors, and genetic factors may be associated with an apparently high incidence of the familial occurrence of germ cell tumors in Japan.

\section{Conflicts of Interest Disclosure}

The authors have no personal financial or institutional interest in any of drugs, materials, or devices in the article. All authors who are members of The Japan Neurosurgical Society (JNS) have registered online Self-reported COI Disclosure Statement Forms through the website for JNS members.

\section{References}

1) Aita JA: Genetic aspects of tumors of the nervous system. II. Nebr State Med J 53: 302-304, 1968

2) Aoyama I, Kondo A, Ogawa H, Ikai Y: Germinoma in siblings: case reports. Surg Neurol 41: 313-317, 1994

3) Fisher JL, Schwartzbaum JA, Wrensch M, Wiemels JL: Epidemiology of brain tumors. Neurol Clin 25: 867-890, vii, 2007

4) Greene MH, Kratz CP, Mai PL, Mueller C, Peters JA, Bratslavsky G, Ling A, Choyke PM, Premkumar A, Bracci J, Watkins RJ, McMaster ML, Korde LA: Familial testicular germ cell tumors in adults: 2010 summary of genetic risk factors and clinical phenotype. Endocr Relat Cancer 17: 109-121, 2010

5) Kanetsky PA, Mitra N, Vardhanabhuti S, Li M, Vaughn DJ, 
Letrero R, Ciosek SL, Doody DR, Smith LM, Weaver J, Albano A, Chen C, Starr JR, Rader DJ, Godwin AK, Reilly MP, Hakonarson H, Schwartz SM, Nathanson KL: Common variation in KITLG and at 5q31.3 predisposes to testicular germ cell cancer. Nat Genet 41: 811-815, 2009

6) Kido G, Takeuchi T, Tsukiyama T, Nakamura S, Tsubokawa T, Henmi A: [Tumor of the pineal region in three brothers]. No Shinkei Geka 12: 975-980, 1984 (Japanese)

7) Nakamura H, Makino K, Yano S, Kuratsu J; Kumamoto Brain Tumor Research Group: Epidemiological study of primary intracranial tumors: a regional survey in Kumamoto prefecture in southern Japan-20-year study. Int J Clin Oncol 16: 314-321, 2011

8) Nakamura H, Takeshima H, Makino K, Kuratsu J: C-kit expression in germinoma: an immunohistochemistry-based study. J Neurooncol 75: 163-167, 2005

9) Nakasu S, Handa J, Hazama F, Hirakawa K: Suprasellar yolksac tumor in two sisters. Surg Neurol 20: 147-151, 1983

10) Rapley EA, Turnbull C, Al Olama AA, Dermitzakis ET, Linger R, Huddart RA, Renwick A, Hughes D, Hines S, Seal S, Morrison J, Nsengimana J, Deloukas P; UK Testicular Cancer
Collaboration, Rahman N, Bishop DT, Easton DF, Stratton MR: A genome-wide association study of testicular germ cell tumor. Nat Genet 41: 807-810, 2009

11) Sakuma Y, Sakurai S, Oguni S, Satoh M, Hironaka M, Saito $\mathrm{K}$ : c-kit gene mutations in intracranial germinomas. Cancer Sci 95: 716-720, 2004

12) Wakai S, Segawa H, Kitahara S, Asano T, Sano K, Ogihara R, Tomita S: Teratoma in the pineal region in two brothers. Case reports. J Neurosurg 53: 239-243, 1980

13) Wang HW, Wu YH, Hsieh JY, Liang ML, Chao ME, Liu DJ, Hsu MT, Wong TT: Pediatric primary central nervous system germ cell tumors of different prognosis groups show characteristic miRNome traits and chromosome copy number variations. BMC Genomics 11: 132, 2010

Address reprint requests to: Naoki Nitta, MD, PhD, Department of Neurosurgery, Shiga University of Medical Science, Seta-Tsukinowa-cho, Otsu, Shiga 520-2192, Japan. e-mail:nnitta@belle.shiga-med.ac.jp 